\title{
Analysis of Marine Pollution of Ports and Jetties in Rivers State, Nigeria
}

\author{
Samson Nitonye, Ofanson Uyi \\ Department of Marine Engineering, Rivers State University, Port Harcourt, Nigeria \\ Email: nitonye.samson@ust.edu.ng
}

How to cite this paper: Nitonye, S. and Uyi, O. (2018) Analysis of Marine Pollution of Ports and Jetties in Rivers State, Nigeria. Open Journal of Marine Science, 8, 114-135. https://doi.org/10.4236/ojms.2018.81006

Received: December 22, 2017

Accepted: January 22, 2018

Published: January 25, 2018

Copyright $\odot 2018$ by authors and Scientific Research Publishing Inc. This work is licensed under the Creative Commons Attribution International License (CC BY 4.0).

http://creativecommons.org/licenses/by/4.0/

\begin{abstract}
Ports and jetties complex operations come with various forms of pollutions. The analysis of marine pollution from ports becomes very necessary and complicated due to the various types of pollution, sources, effects and different characteristics. The sources of environmental pollution other than ships and from industrial activities in port and jetties were critically looked at and analyzed. A complete review of the environmental pollution in ports and the tools to assess and minimize such negative environmental impact are analyzed. The instrument of questionnaires was employed and distributed among two seaports and one jetty; Onne, Okrika and Port Harcourt to collect respondents' opinions on effects, sources and causes of marine pollution. The chi-square test for independence was used with 180 respondents from Onne port, Port Harcourt port and Okrika jetty. Water sample was collected from Onne seaport and pollution contents such as total petroleum hydrocarbon (TPH), bio-chemical oxygen demand (BOD), turbidity, $\mathrm{pH}$ and salinity were tested in the laboratory. The result shows that Onne water had a salinity level of $20,790(\mathrm{mg} / \mathrm{l})$ which under the salinity range of water is considered saline, a turbidity level of 4.00 (NTU) which was considered average comparing with a 5.00 (NTU) bench mark, BOD5 level of $0.48(\mathrm{mg} / \mathrm{l})$ which was considered pristine because most pristine seawater will have BOD below $1(\mathrm{mg} / \mathrm{l}), \mathrm{pH}$ level of 7.77 which falls under the range of sea water being alkaline (7.2 - 8.4), TPH level of $2.98(\mathrm{mg} / \mathrm{l})$ since all conditions of sampling and sample preservations were observed and the value is less than the DPR limit $(10 \mathrm{mg} / \mathrm{l})$. It was concluded that the activities in Onne port are within the acceptable limits. It was also observed from the questionnaire that a larger population of respondents in Onne, Okrika and Port Harcourt ports where conscious of the sources and effects of environmental pollution from their respective ports.
\end{abstract}

\section{Keywords}

Pollution, Ports, Ships, Salinity, Sea Water, Onne, Okrika, Port Harcourt 


\section{Introduction}

Ports are characterized by several complex operations, when compared with other logistic nodes. Environmental pollution analysis from ports and Jetties are complicated due to the various types of pollution, sources and their different characteristics. Pollution from port areas comes not only from ferries, ships and trade but also from industrial and shipyard activities as well as auxiliary services. Port pollution can produce negative effects both to the natural eco-system and to the urban population [1] [2]. The $7^{\text {th }}$ goal of the Millennium Development is to ensure clean environmental sustainability. The pursuit of environmental sustainability is an essential part of human well-being [3]. However, environmental pollution from ports and jetties is inevitable phenomenon so long as port operations exist. Owing to the alarming rate at which toxic and hazardous wastes are being generated, the Federal Environmental Protection Decree (FEPD) was promulgated in 1988 which later led to the birth of Federal Environmental Protection Agency (FEPA) which developed a national policy on Environment. In 1999, a full-fledged ministry was formed to deal with environmental issues [4]. Marine operations in ports have to a large extent caused environmental pollution which affects the normal living conditions of both human and aquatic life. The sources of environmental pollution from ports can be from tanker accidents, noise pollution, marine machinery exhaust, wastewater discharge from ships, ballast water discharge from ships at ports, oily water discharge from ships, garbage and other solid waste, anti-fouling paints and so on [5] [34].

In ports, jetties and harbors, cargo handling operations could cause accidental discharges and emissions. Handling of dry bulk produces dust and liquid bulks may cause leaks, spillages and atmospheric pollution can come from cargo vapour emissions [6]. Any release of cargoes or wastes into the marine environment has direct effect on the environment, which may result in oxygen depletion on their breakdown. Most pollution from ports are caused by human error or negligence either directly or indirectly through the introduction of substances or energy into the marine environment including estuaries, waste-water generated by cleaning of port docks, cleaning of ships and leakages of liquid from goods. All these causes harm to living resources, hit on marine life, decline in seafood production, hazard to human health (skin and lungs diseases to port workers), hindrance to marine activities including fishing, impairment of quality for use of sea-water and reduction of amenities [7].

This work will examine the effects of environmental pollution from seaports and jetty at Onne, Okrika and Port Harcourt with a view to analyze the pollution content, protect and maintain the quality of the environment in the ports and jetties in Rivers State of Nigeria. The work will also proffer solutions to environmental pollution from marine activities in ports and jetties in Rivers State. The International Maritime Organization (IMO) in 2014 estimated that $\mathrm{CO}_{2}$ from shipping were equal to $2.2 \%$ of the global human-made emissions in 2012 and is expected to rise as much as 2 to 3 times by 2050 if no conscious effort is 
made to stop it [6] [8]. In the first Intercessional Meeting of the IMO Working Group on greenhouse gas emissions from Ships that took place in Oslo, Norway from 23 to 27 June, 2008, the organization was given the task to develop the technical framework for the reduction mechanisms that may form part of future IMO regime to control greenhouse gas emissions from international shipping, and a draft of the actual reduction mechanisms themselves for further consideration by IMO's Marine Environment Protection Committee (MEPC) [9].

\section{Sources of Marine Pollution}

The various sources of marine pollution from ports and jetties are enormous; which ranges from tanker accidents, noise, marine machinery exhaust, wastewater discharge from ships, ballast water discharge from ports and jetties, oily water discharge from ships, garbage and other solid waste to anti-fouling paints and many more as shown in Figure 1.

Ballast water discharge from ships has negative impact on the marine environment, especially bigger vessels like cruise ships, large tankers and heavy bulk cargo carriers that handles large amount of ballast water. Discharged ballast water contains a variety of biological materials, which may include plants, animals, viruses, and bacteria etc. These materials like non-native, nuisance, invasive, exotic species that can cause extensive ecological and economic damage to aquatic ecosystems along with serious human health problems must be checked. Noise is another form of pollution that has increased because of large shipping activities and other human enterprises in recent times. The noise produced by ships can travel long distances. Marine species that may rely on sound for their orientation, communication and feeding, can be harmed by this sound pollution [11] [12].

Other sources of marine pollution could come from industries sited close to the marine environment as shown in Figure 2. Around the ports and jetties in Rivers State we can find industries like the Refinery, Fertilizer Company, shipyards, multinational oil and gas companies, chemical industries etc with their attendant pollution problem such as harmful chemicals, plastics, toxins, shipyard waste and other industrial waste are discharged into the marine environment, thereby becoming another major source of marine pollution[13]. Exhaust

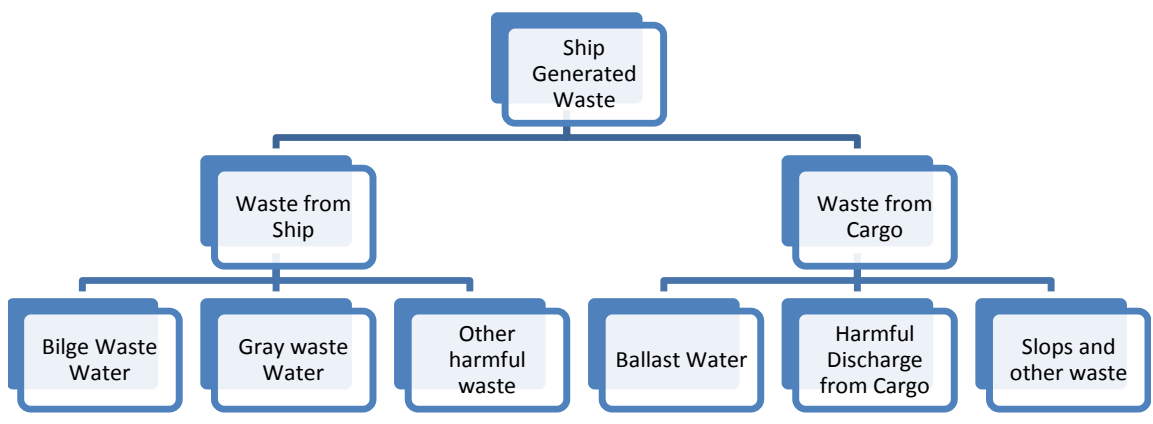

Figure 1. Classification of ship and cargo generated waste discharged in and out of the port environment. Source: adapted from [10]. 


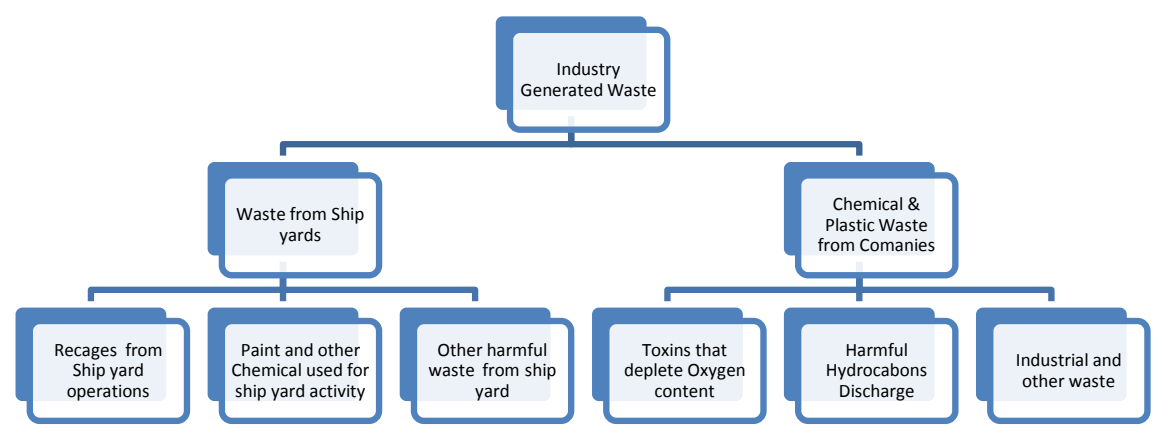

Figure 2. Classification of Industry generated waste discharged in and out of the port environment. Source: adapted from [10].

gases from ships are considered to be a significant source of air pollution, both for conventional pollutants and greenhouse gases. There is a perception that cargo transported by ship is low in air pollutants because for equal weight and distance, it is the most efficient transport method. This is particularly true in comparison to air freight; however, because sea shipment accounts for far more annual tonnage and the distances are often large, shipping emissions are globally substantial [14] [35].

The emission of gases like sulfur dioxide, nitrogen oxide, carbon monoxide, carbon dioxide, and other hydrocarbons generated by diesel engines of ships burning high sulfur content fuel oil into the air is another source of marine pollution. Diesel exhaust has been classified by Environmental Protection Agency (EPA) as carcinogenic. EPA recognizes that these emissions from marine diesel engines contribute to the depletion of the ozone layer, climate change and as well has adverse health effects associated with ambient concentrations of particulate matter and visibility, haze, acid deposition, Eutrophication and nitrification of water. EPA estimates that large marine diesel engines accounted for about 1.6 percent of mobile source nitrogen oxide emissions and 2.8 percent of mobile source particulate emissions in the United States in 2000 [14]. The total global emission of $\mathrm{NO}_{\mathrm{x}}$ and $\mathrm{SO}_{\mathrm{x}}$ shipping contributes more than 20 percent and 10 percent respectively. Acid rain from sulphur destroys crops, buildings and causes heart attack. The European Environmental coalition through Irene Blooming said "A ship lets out around 50 times more sulfur than a lorry per metric tons of cargo carried." Cities in the U.S having heaviest shipping traffic have left local officials desperately trying to clean up the air [15] [16].

Another pollution associated with ports, jetties and ships is oil spills and its attendant challenges. Over ten percent of all climate change emissions are caused by shipping and ports activities. One source of environmental stresses on maritime vessels recently has come from states and localities, as they assess the contribution of commercial marine vessels to regional air quality problems when ships are docked at port. When MARPOL (Annex VI) came into full manifestation in 2015 it has the mandate to combat these problems. As such cruise ships now employ CCTV monitoring on the smokestacks as well as recorded measuring 
via opacity meter while some are also using clean burning gas turbines for electrical loads and propulsion in sensitive areas [17]. The Marine Pollution Treaty were established by international bodies to regulate marine pollution from ships "In general, these treaties tend to emphasize the technical features of safety and pollution control measures without going to the root causes of sub-standard shipping, the absence of incentives for compliance and the lack of enforceability of measures have endangered the safety of the environment" [18].

The impact of shipping activates and port operations with special reference to sewage in 2013 brought MARPOL ANNEX IV into force to restrict untreated waste discharge into the marine environment. To check this, most modern cruise ships are installed with a membrane bioreactor treatment plant to convert all black-water and grey-water to near drinkable quality, to be re-used in the machinery spaces as technical water. Non-oil pollutants and other solid waste from ships are normally dumped into the sea or river when there is no enforcement which must be discouraged. Solid waste generated from ports, jetties and ships like glass, paper, cardboard, aluminum, steel cans, plastics etc that enters the marine environment may pose a threat to marine organisms, humans, coastal communities and industries that utilize marine waters [19] [20]. Another silent pollution source to the marine environment is the use of anti-fouling paint by ports, jetties and ships which can serve as poison when introduced into the environment, impact on marine wildlife and even affect the food chain. This must be checked by regulatory bodies to avoid environmental deserter and decay [21].

\section{Effect and Impact of Marine Pollution}

\subsection{Effect of Marine Pollution}

The effects of marine pollution from ships, ports and jetties are enamors and varies with their causes. Deplete of oxygen content of the water is another serious effect of marine pollution which endangers the life of water animals and humans. An excess of oxygen depleting chemicals in the water can lead to hypoxia (inadequate supply of oxygen) and the creation of a dead zone. Also storm water runoff that travels across paved surfaces can accumulate deposits of air pollution, automotive fluids and sediments. In fact vessel storm water runoff from Marine Ports is a source of impairment in Nigeria coastal waters and its estuaries [5] [22]. Plastic wastes from industries, ports and ships serves as agents of marine pollution and have an effect that cannot be imagined unless witnessed. Sea animals die as a result of the consumption of plastic debris. The introduction of chemical nutrients into water bodies causes Eutrophication on the water surface. This can result to an increase in the ecosystem's primary productivity, cause lack of oxygen and severe reductions in water quality, fish, and other animal populations. Excess nutrients stimulate algal growth and these marine toxins can be transferred to land animals because many animal feeds have a high fish meal or fish hydrolysate content and appear later in meat and dairy products, which becomes hazard to human life when consumed [5] [9] [23]. It is important to say 
here that majority of oil pollution into the marine environment actually comes from land, which is runoffs and waste from the cities, industries and other operations that are harmful to marine life. All these have their serious effects on the aquatic environment.

\subsection{Impact of Pollution on Marine Bio-System}

Oil spills from ports, jetties and ships or introduction of chemicals into the marine environment poses serious danger to fresh water and marine environments, which in turn affects surface resources and a wide range of subsurface organisms that are linked in a complex food chain that includes human food resources. These introduced chemicals affect the marine environment in several ways; physical damages that directly impact wildlife and their habitats and the toxicity of the oil which can poison exposed organisms. Oil contaminates the feathers of seabirds and the fur of seals which destroys the insulating and water proofing properties of the feathers. As the bird tries to maintain its body temperature, it will exhaust its fat reserves and become weakened. Also, oil transferred to the surface of its eggs during incubation reduces their hatchability. Oil pollution also results in disruptions to the cycle of coral reefs, clogging of the gills of fishes thereby resulting in their death and hampering the process of photosynthesis of marine plants leading to their end [24].

\subsection{Impact of Pollution on Local Industries}

One industry that is worst hit by the pollution of the marine environment is the fishing industry. The oil spills from the ports, ships and jetties covers the fishes and as they swallow these poisonous water some die others become weak and endanger the life of anything that will consume them. The economic impact of this pollution is far-reaching since it affects the population of seafood. The local economies of coastal towns that depend on these industries can be devastated by a large scale disaster [25] [26]. Another industry that can be affected and suffer because of marine pollution is the Tourism industry. I remember the Holicruise tourist resort at Isaka Town between Port Harcourt port and Okrika jetty was close and one of the reasons for the closure is environmental pollution amongst others. If spilled oil reaches the shore, it contaminates the inter-tidal zone and the beaches. The local tourist industry suffers as aesthetic beauty of sea shore is lost due to oil slick. Industries that rely on clean seawater for routine operations can also suffer because operations have to be stopped while the water is cleaned. This in turn affects the economy of the community [27] [28].

\subsection{Impact of Marine Pollution on Public Health}

Marine pollution poses a great health challenge to humans because of the importance of the marine environment to the well being of man. Anything that affects the environment will certainly affect him. Oil spill or chemical that are airborne toxins will cause headaches, nausea and long-term problems like cancer. 
Crude oil also contains some amounts of heavy metals that rarely evaporate into the air. These compounds, which include mercury, manganese, nickel and chromium are toxic at high doses. Some like arsenic and lead can damage the nervous system even at relatively low doses [21] [29]. WHO recommended the maximum tolerable consumption in food of $0.3 \mathrm{mg}$ of mercury because it poses a health risk to the human life and other aquatic animals. Since mercury is odorless, invisible and accumulates in fish, it is not easy to detect and can't be avoided by trimming off the skin or other parts. Once in the human body, mercury acts as a neurotoxin, interfering with the brain and nervous system. Exposure to mercury can be particularly hazardous for pregnant women and small children. This can weaken the woman, proper development of the child, delay in walking and talking, shortening attention span and causing learning disabilities. Mental retardation, cerebral palsy, deafness and blindness are also other effects of mercury polluted environment. In adults, mercury poisoning can adversely affect fertility and blood pressure regulation and can cause memory loss, tremors, vision loss and numbness of the fingers and toes. A growing body of evidence suggests that exposure to mercury may also lead to heart disease [24] [28].

\subsection{Monitoring, Control and Preventive Measures of Marine Pollution}

For the Marine environment not to be a dumping ground for waste oil and chemicals, National and International regulations, guidelines and codes were established for the control and prevention of marine environmental pollution. IMO is one of such organizations.

\section{International Maritime Organization (IMO)}

The IMO is responsible for the prevention and control of pollution of the sea from ships while MARPOL 73/78 Convention covers the prevention of pollution of the marine environment by ships from operational or accidental causes. IMO has six technical Annexes currently [20] [30].

Annex I: Regulations is for the prevention of pollution by Oil: This covers oily mixtures, distillates, gasoline, jet fuels, etc.

Annex II: Regulations is for the control of pollution by Noxious liquid substances carried in bulk: This control mainly chemicals including, acids, alcohols, castor oil, hydrogen peroxide, pentanol sodium sulphite, etc., also citric juice, glycerine, milk, molasses, wine, etc. [20].

Annex III: Regulations is for the prevention of pollution by harmful substances carried in packaged form: This contains general requirements for the issuing of detailed standards on packing, marking, labeling, documentation, stowage, quantity limitations, exceptions and notifications for preventing pollution by harmful substances [20].

Annex IV: Regulations is for the prevention of pollution by Sewage waste: This contains a set of regulations regarding the discharge of sewage from any form of toilets; drainage from spaces containing live animals etc. provides facilities at 
port and terminals for the reception of sewage, and requirements for survey and certification of ships.

Annex V: Regulations is for the prevention of pollution by Garbage from ships: This requires the separation of different types of garbage, the specification of the distance from land the garbage will be disposed and the manner in which they may be disposed otherwise, they should be delivered to shore based reception facilities.

Annex VI: Regulations is for the prevention of air pollution from ships: This set limit on sulphur oxide SOx and Nitrogen oxide NOx emissions from ship exhaust as well as prohibits deliberate emissions of Ozone depleting substances, such as Hydro-Chlorofluorocarbons [25] [29].

\subsection{Research Study Area of Marine Pollution Analysis.}

Onne port in Rivers State is located on Latitude/Longitude: $4.6845^{\circ} / 7.1575^{\circ}$, it is also considered as one of the major seaports in Nigeria as shown in Figure 3 [31].

Onne port is the home to many industries and has the highest traffic of vessels into ports in Rivers State. Figure 4 shows the arrival and departure of vessels for one month while Figure 5 and Figure 6 show the arrival of vessels by type at the sea port for 30 days. The main activities at Onne port include export and import of facilities for oil companies, these activities provides significant economic source to its residents. The influx of vessels into Onne port and the traffic of maritime activities have informed the choice of this port for this marine pollution analysis.

\section{Research Materials and Methods}

\subsection{Research Design and Hypothesis}

The research covers the design of hypothesis, population and samplings, sampling technique, data collection and data analysis. Abdullah and Levine said

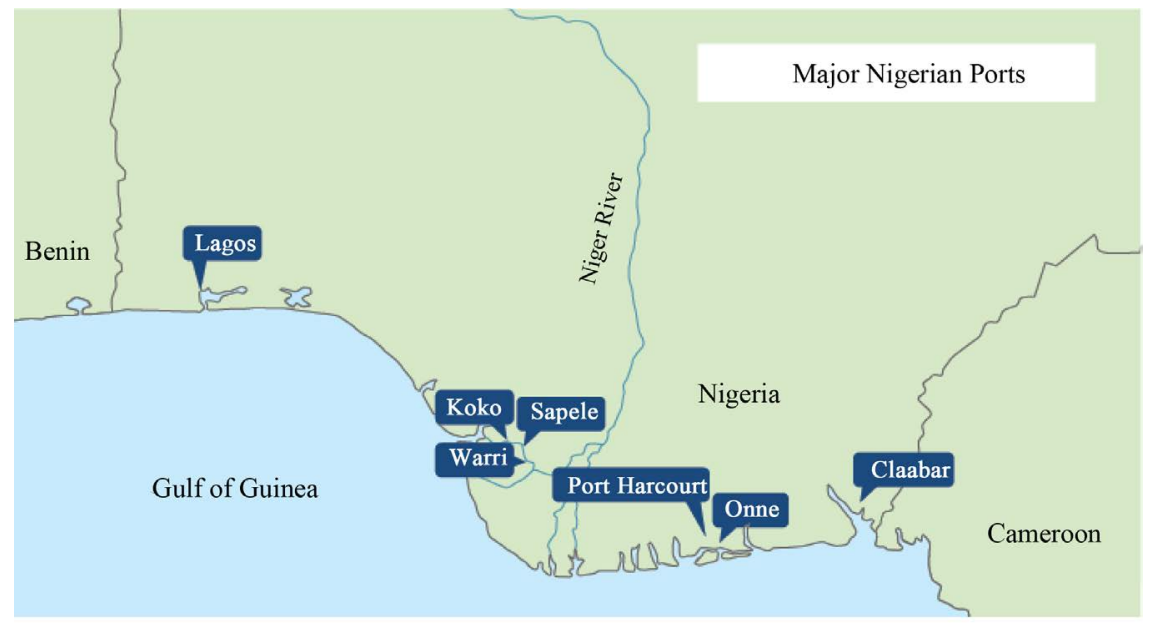

Figure 3. Onne port in rivers state as a major port in Nigeria [31]. 
80

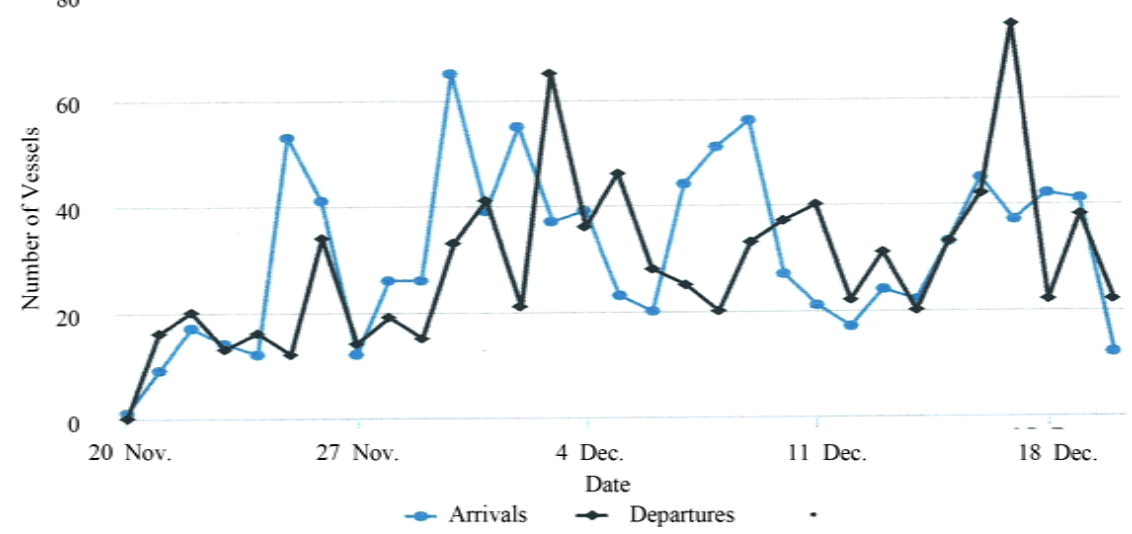

Figure 4. The arrival and departure of vessels for one month at Onne Port [32].

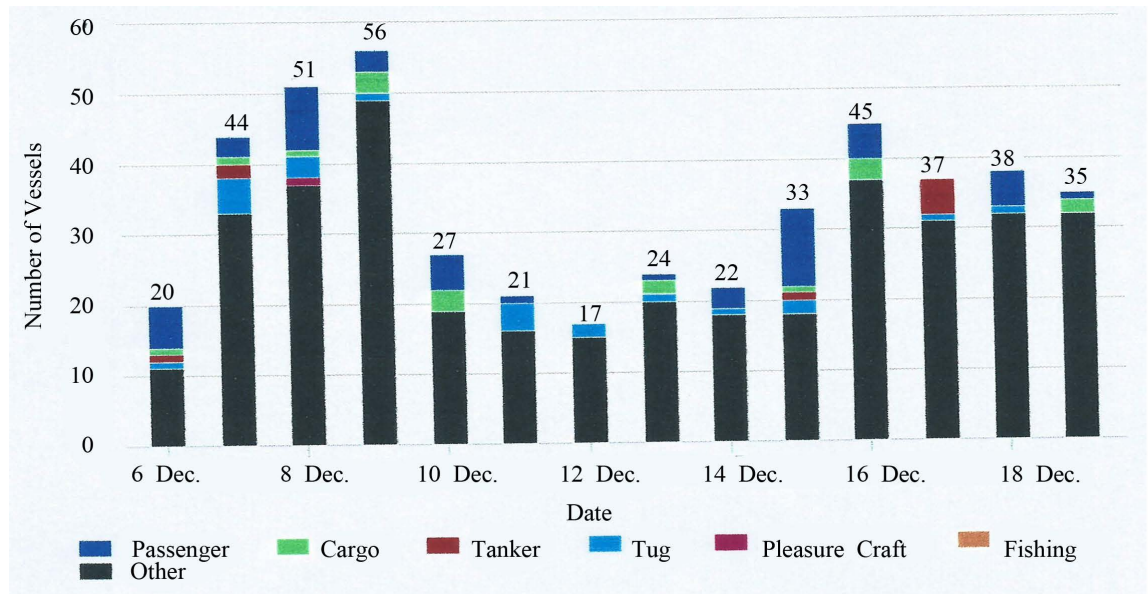

Figure 5. The arrival of vessels by type in Onne port [32].

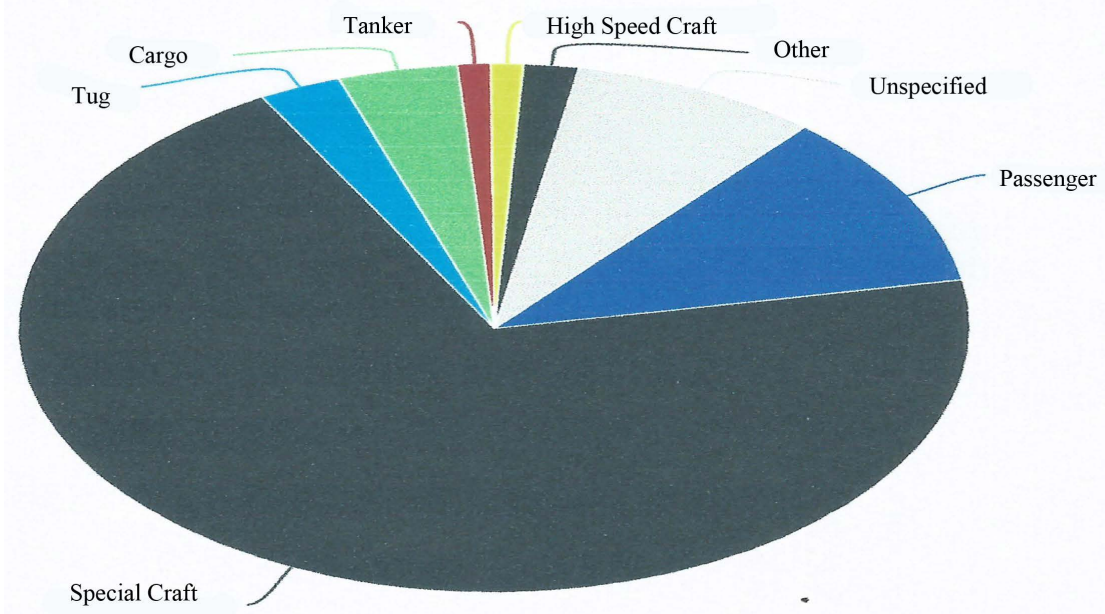

Figure 6. The bar chart of all vessels by type into the sea port for 30 days [32].

research design addresses fundamental question that brings the study into the scope of the research and how yield the required data [33]. The survey method 
was adopted in this research which requires the use of questionnaires, observation, sampling and interview to collect relevant information for the study. The chi-square test for independence was used in the analysis while charts, tables and percentages are used to complement the analysis. The hypothesis is formulated as follows:

- No awareness of the existence of IMO.

- Untreated wastewater discharge from ship does not cause pollution of the marine environment.

- Marine pollution does not affect fishing activities.

- Ship sewage treatment does not help to control the amount of bacteria discharged into water bodies.

- Failure to comply with IMO regulations have not contributed to pollution of Nigerian waterways.

- Oil spill is not the most common source of marine pollution.

- Marine pollution does not affect the immune and endocrine systems of humans [36] [37].

\subsection{Research Sample Size}

Since it is impracticable to study the whole subject of population, the method of sampling is employed in a study. It is believed that good sampling will enable the researcher to generalize his/her feelings to the wider population. Water sample was collected from Onne seaport and the pollution content was tested in the laboratory. The purposive-non-probability sampling methods were used, research questions were formulated and 180 respondents picked at random from Onne Port, Port Harcourt port and Okrika jetty with 60 respondents per port. The pollution content in water sample considered includes Total petroleum hydrocarbon (TPH), Biochemical oxygen demand (BOD), Turbidity, Salinity and $\mathrm{pH}$.

\subsection{Research Equations for Analysis}

Using sample data we find the degrees of freedom, expected frequencies, test statistic, and the P-value associated with the test statistic.

- Degrees of freedom.

$$
D F=(r-1) \times(c-1)
$$

where $r=$ number of levels for one categorical variable and $c=$ number of levels for the other categorical variable.

- Expected frequencies. The expected frequency counts are computed separately for each level of one categorical variable at each level of the other categorical variable. Compute $r^{*} c$ expected frequencies,

$$
E_{r, c}=\frac{n_{r} \times n_{c}}{n}
$$

where $E_{r, c}=$ expected frequency count for level $r$ of Variable A and level $c$ of Variable $\mathrm{B}, n_{r}=$ total number of sample observations at level $r$ of Variable A, 
$n_{c}=$ total number of sample observations at level $c$ of Variable B and $n=$ total sample size.

- Test statistic. The test statistic is a chi-square random variable $\left(X_{c}^{2}\right)$ defined by the following equation.

$$
X_{c}^{2}=\sum\left[\frac{\left(O_{r, c}-E_{r, c}\right)^{2}}{E_{r, c}}\right][33]
$$

where $X_{c}^{2}=$ calculated chi-square and $\Sigma=$ summation sign, $O_{r, c}=$ observed frequency count at level $r$ of Variable $\mathrm{A}$ and level $c$ of Variable B and $E_{r, c}=$ expected frequency count at level $r$ of Variable A and level $c$ of Variable B.

- P-value. The P-value is the probability of observing a sample statistic as extreme as the test statistic. Since the test statistic is a chi-square, the Chi-Square Distribution Calculator is used to assess the probability associated with the test statistic. Use the degrees of freedom computed above [33].

The decision rule in the use of chi-square is that if the sample findings are unlikely, given the null hypothesis, then reject the null hypothesis. These involve comparing the P-value to the significance level, reject the null hypothesis when the P-value is less than the significance level.

\section{Research Analysis from the Hypotheses}

1) No awareness of the existence of IMO: The research question shows that there is awareness of the existence of IMO in Nigeria ports. Table 1 shows the response from the respondent for Hypotheses I to VII

$$
\begin{gathered}
D F=(r-1) \times(c-1) \\
(2-1) \times(3-1)=2 \\
E_{r, c}=\frac{n_{r} \times n_{c}}{n} \\
E_{1,1}=E_{1,2}=E_{1,3}=\frac{125 \times 60}{180}=41.6 \\
E_{2,1}=E_{2,2}=E_{2,3}=\frac{55 \times 60}{180}=18.33 \\
X_{c}^{2}=\sum\left[\frac{\left(O_{r, c}-E_{r, c}\right)^{2}}{E_{r, c}}\right] \therefore X_{c}^{2}=9.15
\end{gathered}
$$

2) Untreated wastewater discharge from ship does not cause pollution of the marine environment. The research question shows that marine environmental pollution can be caused by untreated wastewater discharge from ships.

$$
\begin{gathered}
D F=(r-1) \times(c-1) \\
(2-1) \times(3-1)=2 \\
E_{r, c}=\frac{n_{r} \times n_{c}}{n}
\end{gathered}
$$


Table 1. Response to hypothesis I to VII.

\begin{tabular}{|c|c|c|c|c|c|}
\hline Response & Option & ONNE & OKRIKA & $\begin{array}{c}\text { PORT } \\
\text { HARCOURT }\end{array}$ & $\begin{array}{c}\text { ROW } \\
\text { TOTAL }\end{array}$ \\
\hline & No (Disagree) & 40 & 35 & 50 & 125 \\
\hline \multirow[t]{3}{*}{ Hypothesis I } & Yes (Agree) & 20 & 25 & 10 & 55 \\
\hline & Column Total & 60 & 60 & 60 & 180 \\
\hline & No (Disagree) & 48 & 57 & 56 & 161 \\
\hline \multirow[t]{3}{*}{ Hypothesis II } & Yes (Agree) & 12 & 3 & 4 & 19 \\
\hline & Column total & 60 & 60 & 60 & 180 \\
\hline & No (Disagree) & 58 & 49 & 57 & 164 \\
\hline \multirow[t]{3}{*}{ Hypothesis III } & Yes (Agree) & 2 & 11 & 16 & 16 \\
\hline & Column Total & 60 & 60 & 60 & 180 \\
\hline & No (Disagree) & 51 & 53 & 42 & 146 \\
\hline \multirow[t]{3}{*}{ Hypothesis IV } & Yes (Agree) & 9 & 7 & 18 & 34 \\
\hline & Column Total & 60 & 60 & 60 & 180 \\
\hline & No (Disagree) & 55 & 41 & 51 & 147 \\
\hline \multirow[t]{3}{*}{ Hypothesis V } & Yes (Agree) & 5 & 19 & 9 & 33 \\
\hline & Column Total & 60 & 60 & 60 & 180 \\
\hline & No (Disagree) & 28 & 35 & 18 & 81 \\
\hline \multirow[t]{3}{*}{ Hypothesis VI } & Yes (Agree) & 32 & 25 & 42 & 99 \\
\hline & Column Total & 60 & 60 & 60 & 180 \\
\hline & No (Disagree) & 42 & 36 & 50 & 128 \\
\hline \multirow[t]{2}{*}{ Hypothesis VII } & Yes (Agree) & 18 & 24 & 10 & 52 \\
\hline & Column Total & 60 & 60 & 60 & 180 \\
\hline \multicolumn{6}{|c|}{$E_{1,1}=E_{1,2}=E_{1,3}=\frac{161 \times 60}{180}=53.66$} \\
\hline \multicolumn{6}{|c|}{$E_{2,1}=E_{2,2}=E_{2,3}=\frac{19 \times 60}{180}=6.33$} \\
\hline & $X_{c}^{2}=\sum[$ & $\left.E_{r, c}\right)^{2}$ & $\therefore X_{c}^{2}=$ & & $(10$ \\
\hline
\end{tabular}

3) Marine pollution does not affect fishing activities. The research question shows that fishing activity can affect the pollution of the marine environment.

$$
\begin{gathered}
D F=(r-1) \times(c-1) \\
(2-1) \times(3-1)=2 \\
E_{r, c}=\frac{n_{r} \times n_{c}}{n} \\
E_{1,1}=E_{1,2}=E_{1,3}=\frac{164 \times 60}{180}=54.66
\end{gathered}
$$




$$
\begin{gathered}
E_{2,1}=E_{2,2}=E_{2,3}=\frac{16 \times 60}{180}=5.33 \\
X_{c}^{2}=\sum\left[\frac{\left(O_{r, c}-E_{r, c}\right)^{2}}{E_{r, c}}\right] \quad X_{c}^{2}=10.00
\end{gathered}
$$

4) Ship sewage treatment do not control the amount of bacteria discharged into water bodies. The research question shows that ship sewage treatment help to control the amount of bacteria discharged into water bodies.

$$
\begin{gathered}
D F=(r-1) \times(c-1) \\
(2-1) \times(3-1)=2 \\
E_{r, c}=\frac{n_{r} \times n_{c}}{n} \\
E_{1,1}=E_{1,2}=E_{1,3}=\frac{146 \times 60}{180}=48.66 \\
E_{2,1}=E_{2,2}=E_{2,3}=\frac{34 \times 60}{180}=11.33 \\
X_{c}^{2}=\sum\left[\frac{\left(O_{r, c}-E_{r, c}\right)^{2}}{E_{r, c}}\right] X_{c}^{2}=7.453
\end{gathered}
$$

5) Failure to comply with IMO regulations have not contributed to pollution of Nigeria waterways. The research question shows that disobedience to IMO regulations contribute to pollution of Nigeria waterways.

$$
\begin{gathered}
D F=(r-1) \times(c-1) \\
(2-1) \times(3-1)=2 \\
E_{r, c}=\frac{n_{r} \times n_{c}}{n} \\
E_{1,1}=E_{1,2}=E_{1,3}=\frac{147 \times 60}{180}=49 \\
E_{2,1}=E_{2,2}=E_{2,3}=\frac{33 \times 60}{180}=11 \\
X_{c}^{2}=\sum\left[\frac{\left(O_{r, c}-E_{r, c}\right)^{2}}{E_{r, c}}\right] X_{c}^{2}=11.55
\end{gathered}
$$

6) Marine pollution does not affect the immune and endocrine systems of humans. The research question shows that the human immune and endocrine system can be affect by marine pollution.

$$
\begin{gathered}
D F=(r-1) \times(c-1) \\
(2-1) \times(3-1)=2 \\
E_{r, c}=\frac{n_{r} \times n_{c}}{n}
\end{gathered}
$$




$$
\begin{gathered}
E_{1,1}=E_{1,2}=E_{1,3}=\frac{81 \times 60}{180}=27 \\
E_{2,1}=E_{2,2}=E_{2,3}=\frac{99 \times 60}{180}=33 \\
X_{c}^{2}=\sum\left[\frac{\left(O_{r, c}-E_{r, c}\right)^{2}}{E_{r, c}}\right] X_{c}^{2}=9.81
\end{gathered}
$$

7) Oil spill is not the most common source of marine pollution. The research question shows that oil spill is the most common source of marine pollution.

$$
\begin{gathered}
D F=(r-1) \times(c-1) \\
(2-1) \times(3-1)=2 \\
E_{r, c}=\frac{n_{r} \times n_{c}}{n} \\
E_{1,1}=E_{1,2}=E_{1,3}=\frac{128 \times 60}{180}=42.66 \\
E_{2,1}=E_{2,2}=E_{2,3}=\frac{52 \times 60}{180}=17.33 \\
X_{c}^{2}=\sum\left[\frac{\left(O_{r, c}-E_{r, c}\right)^{2}}{E_{r, c}}\right] X_{c}^{2}=8.00
\end{gathered}
$$

\section{Results and Discussion}

Table 2 and Table 3 show the comparison of the observed and expected and the Social-Economic information of staff of Onne, Okrika and Port Harcourt

Table 2. Comparison of the observed and expected response (Hypothesis I to VII).

\begin{tabular}{ccccc}
\hline Response & Option & ONNE & OKRIKA & PORT HARCOURT \\
\hline Hypothesis I & Observed & 40 & 35 & 50 \\
& Expected & 41.6 & 41.6 & 41.6 \\
Hypothesis II & Observed & 48 & 57 & 56 \\
& Expected & 53.66 & 53.66 & 53.66 \\
Hypothesis III & Observed & 58 & 49 & 57 \\
& Expected & 54.66 & 54.66 & 54.66 \\
Hypothesis IV & Observed & 51 & 53 & 42 \\
& Expected & 48.66 & 48.66 & 48.66 \\
Hypothesis V & Observed & 55 & 41 & 51 \\
& Expected & 49 & 49 & 49 \\
Hypothesis VI & Observed & 28 & 35 & 18 \\
& Expected & 27 & 27 & 27 \\
Hypothesis VII & Observed & 42 & 36 & 50 \\
& Expected & 42.66 & 42.66 & 42.66 \\
\hline
\end{tabular}


Table 3. Social-Economic information of staffs of Onne, Okrika and Port Harcourt port.

\begin{tabular}{|c|c|c|c|c|c|c|}
\hline \multirow[b]{2}{*}{ Sex } & \multicolumn{2}{|c|}{ ONNE } & \multicolumn{2}{|c|}{ OKRIKA } & \multicolumn{2}{|c|}{ PORT HARCOURT } \\
\hline & Frequency & Percent (\%) & frequency & Percent (\%) & frequency & Percent (\%) \\
\hline Male & 41 & 68.3 & 48 & 80 & 38 & 63.3 \\
\hline Female & 19 & 31.6 & 12 & 20 & 22 & 36.6 \\
\hline Total & 60 & 100.0 & 60 & 100.0 & 60 & 100.0 \\
\hline Age & frequency & Percent (\%) & frequency & Percent (\%) & frequency & Percent (\%) \\
\hline $30-39$ & 18 & 30 & 20 & 33.3 & 21 & 35 \\
\hline $40-49$ & 19 & 31.6 & 24 & 40 & 15 & 25 \\
\hline 50 above & 23 & 38.3 & 16 & 26.6 & 24 & 40 \\
\hline Total & 60 & 100.0 & 60 & 100.0 & 60 & 100.0 \\
\hline Marital status & frequency & Percent (\%) & frequency & Percent (\%) & frequency & Percent (\%) \\
\hline Single & 17 & 28.3 & 19 & 31.6 & 22 & 36.6 \\
\hline Married & 39 & 65 & 40 & 66.6 & 38 & 63.3 \\
\hline Others & 4 & 6.6 & 1 & 1.6 & 0 & 0 \\
\hline Total & 60 & 100.0 & 60 & 100.0 & 60 & 100.0 \\
\hline Education & frequency & Percent (\%) & frequency & Percent (\%) & frequency & Percent (\%) \\
\hline Primary & 3 & 5 & 7 & 11.6 & 1 & 1.6 \\
\hline Secondary & 9 & 15 & 22 & 36.6 & 10 & 16.6 \\
\hline Tertiary & 48 & 80 & 31 & 51.6 & 49 & 81.6 \\
\hline Total & 60 & 100.0 & 60 & 100.0 & 60 & 100.0 \\
\hline
\end{tabular}

port respectively. From Figure 7, the category with the largest difference between observed and expected value makes the largest contribution to the overall chi-square statistic. In this case, the largest contribution comes from Port Harcourt port. At significance level of $5 \%$ that is 0.05 , using chi-square probability calculator-formula. Inputting values of $X_{c}^{2}=9.15$ and $D F=2, P$-value $=$ 0.0103 . Since the $P$-value is less than the level of significance $(0.0103<0.05)$, we reject the null hypothesis. Hence, we conclude that there is awareness of the existence of IMO. Similarly Figure 8 shows that the largest contribution comes from Onne port. At significance level of $5 \%$ that is 0.05 , using chi-square probability calculator-formula. Inputting values of $X_{c}^{2}=8.562$ and $D F=2, P$-value $=$ 0.0138 . Since the $P$-value is less than the level of significance $(0.0138<0.05)$, we reject the null hypothesis. Hence, we conclude that untreated wastewater discharge from ship causes pollution of the marine environment.

Similarly Figure 9 shows the largest contribution comes from Okrika jetty. At significance level of $5 \%$ that is 0.05 , using chi-square probability calculatorformula. Inputting values of $X_{c}^{2}=10.00$ and $D F=2, P$-value $=0.0067$. Since the $P$-value is less than the level of significance $(0.0067<0.05)$, we reject the null hypothesis. Hence, we conclude that marine pollution causes hindrance in fishing activities. Furthermore Figure 10 shows that the largest contribution comes 


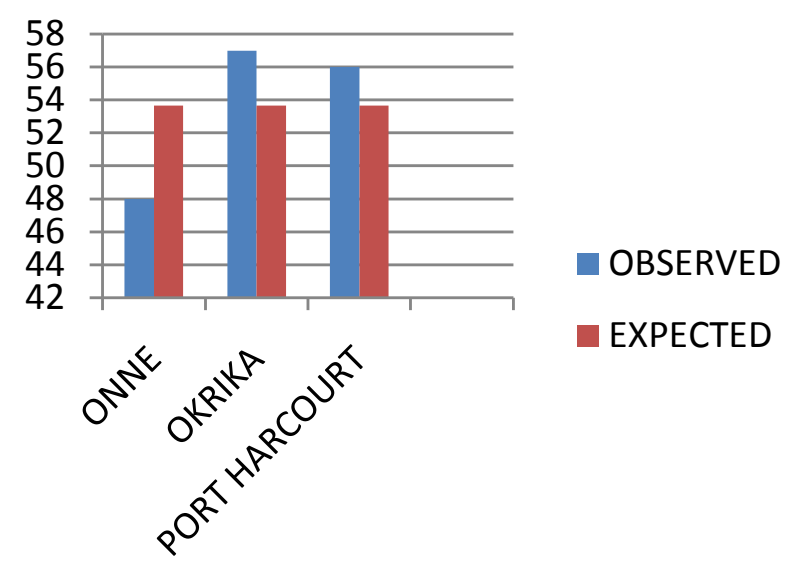

Figure 7. Observed and expected value for $\mathrm{H}-1$.

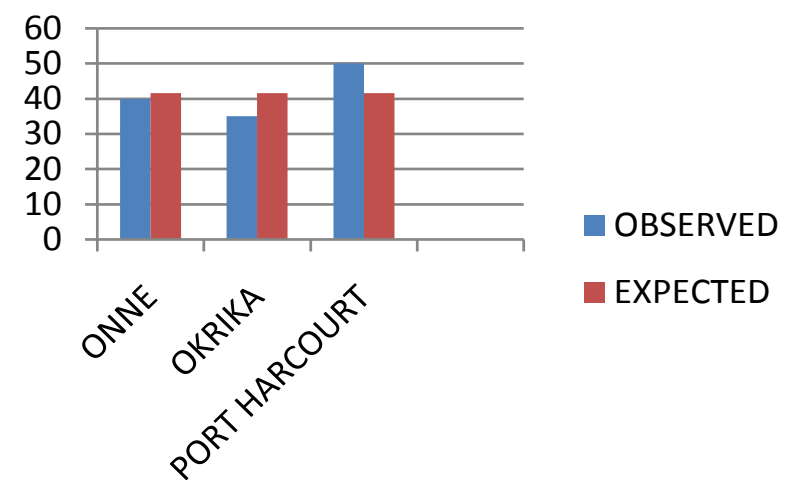

Figure 8. Observed and expected value for H-II.

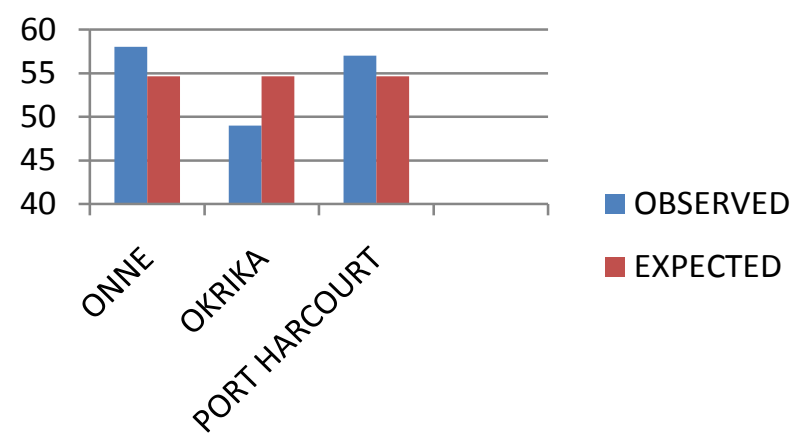

Figure 9. Observed and expected value for H-III.

from Port Harcourt port. At significance level of $5 \%$ that is 0.05 , using chisquare probability calculator-formula. Inputting values of $X_{c}^{2}=7.453$ and $D F=$ 2, $P$-value $=0.0240$. Since the $P$-value is less than the level of significance $(0.0240<$ 0.05 ), we reject the null hypothesis. Thus, we conclude that ship sewage treatment help to control the amount of bacteria discharged into water bodies.

Figure 11 shows that the largest contribution comes from Okrika jetty. At significance level of $5 \%$ that is 0.05 , using chi-square probability calculator-formula. Inputting values of $X_{c}^{2}=11.55$ and $D F=2, P$-value $=0.0031$. 
Since the $P$-value is less than the level of significance $(0.0031<0.05)$, we reject the null hypothesis. Thus, we conclude that failure to comply with IMO regulations have contributed to pollution of Nigeria waterways. Similarly from Figure 12, the largest contribution comes from Okrika jetty. At significance level of 5\% that is 0.05 , using chi-square probability calculator-formula. Inputting values of $X_{c}^{2}=8.00$ and $D F=2, P$-value $=0.0074$. Since the $P$-value is less than the level of significance $(0.0074<0.05)$, we reject the null hypothesis. Thus, we conclude

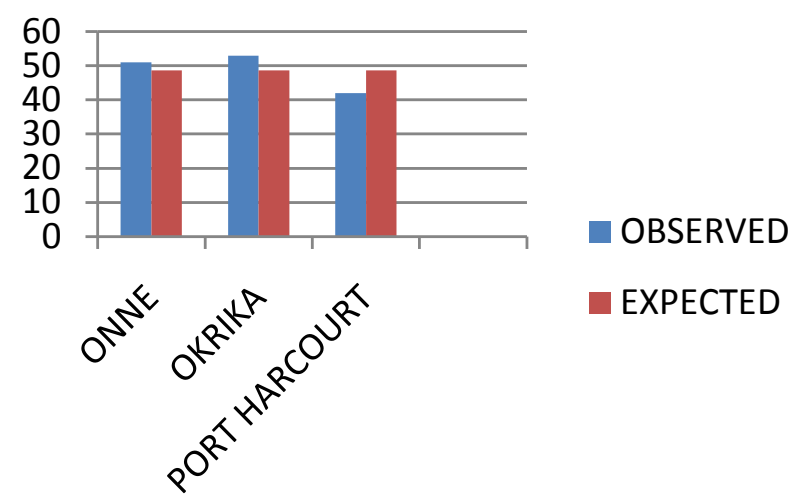

Figure 10. Observed and expected value for $\mathrm{H}-1 \mathrm{~V}$.

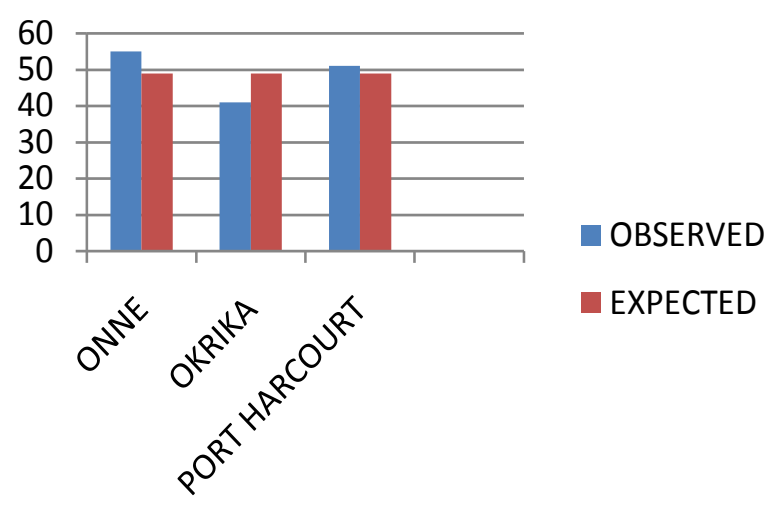

Figure 11. Observed and expected value for $\mathrm{H}-\mathrm{V}$.

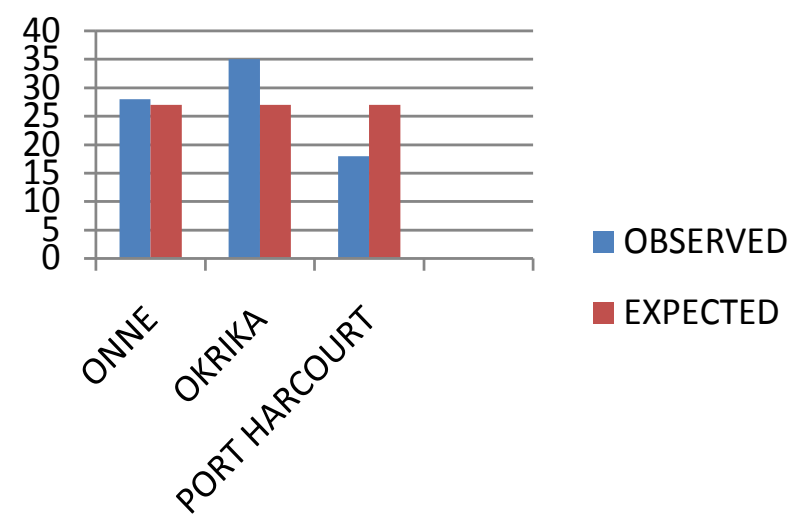

Figure 12. Observed and expected value for H-VI. 
that marine pollution affects the immune and endocrine system of humans.

Figure 13 shows the largest contribution comes from Port Harcourt port. At significance level of $5 \%$ that is 0.05 , using chi-square probability calculatorformula. Inputting values of $X_{c}^{2}=8.00$ and $D F=2, P$-value $=0.0183$. Since the $P$-value is less than the level of significance $(0.0183<0.05)$, we reject the null hypothesis. Thus, we conclude that oil spill is the most common source of marine pollution.

\section{SALINITY AND $\mathrm{pH}$}

The salinity and $\mathrm{pH}$ of the water sample from the Onne port were analyzed with HANNA MULTIPARAMETER EQUIPMENT. This involves standardizing the equipment with solutions that were bought with the equipment, cleaning the probes very well with distilled water after standardizing, dipping the probe in the sample collected in a beaker and taking the necessary reading as displayed on the screen. Table 4 shows the result of the analysis.

SALINITY: Salinity is a measure of how much dissolved salts are in the water. Dissolved salts are usually sodium and chloride ions, although there can also be many others such as potassium and bicarbonate ions. Salinity can vary during the year due to rain diluting the salt in the water. Therefore, high salinity is usually recorded in the summer and low salinity in the winter. As a general rule, salinity is relatively low during periods of high flow and vice-versa. Table 5 shows the salinity ranges from fresh to hyper-saline.

From the table, it is seen that the test result falls within 5000 to 35,000 (mg/L). It is concluded that Onne water is salty and safe.

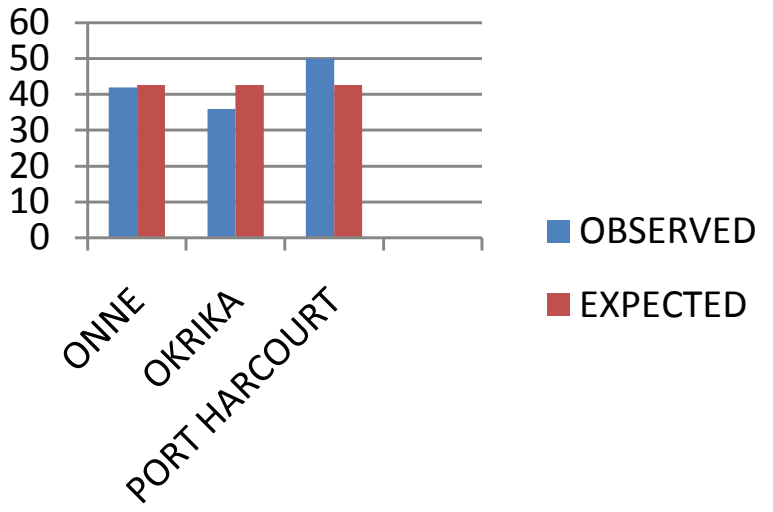

Figure 13. Observed and expected value for H-VII.

Table 4. Result of sample analysis.

\begin{tabular}{cc}
\hline Salinity $(\mathrm{mg} / \mathrm{l})$ & 20,790 \\
Turbidity (NTU) & 4.00 \\
$\mathrm{BOD}_{5}(\mathrm{mg} / \mathrm{l})$ & 0.48 \\
$\mathrm{pH}$ & 7.77 \\
$\mathrm{TPH}(\mathrm{mg} / \mathrm{l})$ & 2.98 \\
\hline
\end{tabular}


Table 5. Ranges of salinity in water.

\begin{tabular}{cc}
\hline Salinity $(\mathrm{mg} / \mathrm{L})$ & Category \\
\hline up to 1000 & Fresh \\
1000 to 3000 & Fresh to brackish \\
3000 to 5000 & Brackish \\
5000 to 35,000 & Saline \\
35,000 and above & Hyper-saline \\
\hline
\end{tabular}

TURBIDITY: Turbidity is the cloudiness or haziness of a fluid caused by individual particles that are generally invisible to the naked eye. The lower the value, the clearer the water is. At no time should the turbidity go above $5 \mathrm{Ne}$ phelolometric Turbidity Unit (NTU).

$\mathrm{pH}$ : Seawater is naturally alkaline, with an average $\mathrm{pH}$ of 7.6. The normal $\mathrm{pH}$ range for seawater is $7.2-8.4$. The $\mathrm{pH}$ of seawater is lower around river mouths. BOD5: Biochemical oxygen demand (BOD) measures the uptake rate of dissolved oxygen by the biological organisms in a body of water. The higher the $\mathrm{pH}$ level of the water the lesser the quality of water. Most pristine seawater will have a 5-day carbonaceous BOD below $1 \mathrm{mg} / \mathrm{L}$. Moderately polluted rivers may have a $B O D$ value in the range of 2 to $8 \mathrm{mg} / \mathrm{L}$. Municipal sewage that is efficiently treated by a three-stage process would have a value of about $20 \mathrm{mg} / \mathrm{L}$ or less

TPH: The level Total Petroleum Hydrocarbon (TPH) was found to be 2.98 $(\mathrm{mg} / \mathrm{l})$. Since all conditions of sampling and sample preservations were observed and the value is less than the DPR limit $(10 \mathrm{mg} / \mathrm{l})$, it then means that the activities in Onne port is adhering to standard and the environment is not being polluted.

\section{Conclusion}

In conclusion, it is a fact that marine pollution will severely affect the coastal resources of a city, state and the nation, so it should be avoided. This can be done by obeying the rules and regulations setup by national and international organization concerned with the environment especially the maritime environment. It is a thing of joy to see and know that after proper analysis of the water sample from Onne port the environment is considered safe within the regulatory framework of IMO. It is true that when an environment is not safe, it could endanger the future stability of human health and risk the aquatic life of the fast growing cities like Port Harcourt, Onne and Okrika in Nigeria. The challenges posed by marine pollution from ports on human health, aquatic lives and the environment in general have not yet received full attention which it deserves. The surveys carried out in this work show the sources of marine pollution from ships which have been established to be the discharge of oily water from bilge, invasive organisms from ballast, accidental discharge of oil from tankers ships and operational discharge and so on. The industries around the ports or jetty 
could also contribute to the pollution of the maritime environment by releasing harmful chemical into the sea. The adverse effects of introducing pollutants into the marine environment have also been established in this work. The effects appear to be damaging to the ecosystem, ships life and human health. Control and preventive measures have been established which include adherence and enforcement of standard operations as contained in ANNEX I-VI of IMO conventions. From the result so far, we can say Onne port is operating within the safe limit of IMO regulation and should endeavor to maintain this trend. However, there is need for proper implementation of the maritime regulations in Nigerian waterways. We recommend aggressive implementation of the existing laws, policies and guidelines on port pollution by relevant local and International organization. The government should punish any erring organization or individuals to serve as a deterrent to others, government should encourage and support relevant law enforcement agencies assigned with such duties. This will address the problem of environmental pollution and bring about sustainable urban development in Rivers State in particular and Nigeria in general.

\section{References}

[1] Kamali Walid (2017) Management of Environmental Sustainability of Ports-Focus on Noise Mitigation. 24th International Congress on Sound and Vibration, London. https://www.iiav.org/archives_icsv_last/2017_icsv24/content/papers/papers/full_pa per_1367_20170531184650646

[2] Mesp Noise (2017) Managing the Environmental Sustainability of Ports for Durable Development. http://www.mesp.org/mesp_noise/noise-project

[3] United Nations Environmental Programme UNEP (2004) Human Well Being, Poverty and Ecosystem Services: Exploring the Links, Nairobi, Kenya.

[4] Ifesanya, A. (2004) Sewage Treatment and the Environment: A Case Study of the University College Hospital, Ibadan Waste Sewage Treatment System.

[5] Umo, I. and Nitonye, S. (2015) Effects and Solutions of Marine Pollution from Ships in Nigerian Waterways. International Journal of Scientific and Engineering Research, 6, 81-90. http://www.ijser.org

[6] SustainableShipping.com (2008) IMO Targets Greenhouse Gas Emissions. Petromedia Group, London.

[7] FCEC (2014) Health Effects of Eating Contaminated Fish. http://www.pvsfish.org/index.php/health-effects-of-eating-contaminated-fish

[8] International Maritime Organization (2014) Third IMO GHG Study 2014 (PDF).

[9] International Maritime Organization (2008) Working Group Oslo June 2008. London.

[10] Onwuegbuchunam, D.E., Ebe, T.E., Okoroji, L.I. and Essien, A.E. (2017) An Analysis of Ship-Source Marine Pollution in Nigeria Seaports. Journal of Marine Science and Engineering, 5, 39. http://www.mdpi.com/journal/jmse

[11] Huettel, S. (2004) Human Noise Pollution in Ocean Can Lead Fish Away from Good Habitats and Off to Their Death. University of Bristol, Bristol.

[12] Olayinka, O.S. (2013) Effective Noise Control Measures and Sustainable Development in Nigeria. World Journal of Environmental Engineering, 1, 5-15. 
[13] Bows-Larkin, A., Mander, S., Gilbert, P., Traut, M., Walsh, C. and Anderson, K. (2014) High Seas, High Stakes, Final Report. Tyndall Centre for Climate Change Research, Univ. of Manchester, Manchester.

[14] US Environmental Protection Agency (EPA) (2003) Control of Emissions from New Marine Compression-Ignition Engines at or above 30 Liters Per Cylinder. Final Rule, Federal Register, 68 FR9751, Washington DC.

[15] Schrooten, L., De Vlieger, I., IntPanis, L., Chiffi, C. and Pastori, E. (2009) Emissions of Maritime Transport: A Reference System. Science of the Total Environment, 408, 318-323. https://doi.org/10.1016/j.scitotenv.2009.07.037

[16] Harrabin, R. (2003) EU Faces Ship Clean-Up Call. BBC News. http://news.bbc.co.uk/2/hi/europe/3019686.stm

[17] Vidal, J. (2009) Health Risks of Shipping Pollution Have Been "Underestimated". The Guardian.

[18] Khee-Jin Tan, A. (2006) Vessel-Source Marine Pollution: The Law and Politics of International Regulation. Cambridge University Press, Cambridge.

[19] Environmental Impact of Shipping (2014). https://en.wikipedia.org/wiki/Environmental_impact_of_shipping

[20] International Maritime Organization (2017) Carriage of Chemicals by Ship. http://www.imo.org/en/OurWork/Environment/PollutionPrevention/ChemicalPoll ution/Pages/Default.aspx

[21] Lisa, S. and Shruti, R. (2013) Full Extent of Heavy Metal Contamination in Exxon Oil Spill Still Unknown. http://www.insideclimatenews.org/news/20130715/

[22] Federal Environmental Protection Agency (FEPA) (1988) Federal Environmental Protection Agency Guidelines and Standards for Industrial Waste Management in Nigeria. 46-55.

[23] LightHouse (2016) Marine Pollution: Meaning, Causes, Effects, Control Measures; Important India and Discover India.

https://www.importantindia.com/23704/marine-pollution-meaning-causes-effects-c ontrol-measures/

[24] Natural Resources Defense Council. Mercury Contamination in Fish. http://www.nrdc.org/

[25] International Maritime Organization (2014). http://www.imo.org/OurWork/Environment

[26] Elenwo, E.I. and Akankali, J.A. (2015) The Effects of Marine Pollution on Nigerian Coastal Resources. Journal of Sustainable Development Studies, 8, 209-224.

[27] Balcomb, K.C. (2000) A Whale Researcher and a Former U.S Navy Officer.

[28] National Research Council, Committee on Shipboard Wastes, Clean Ships, Clean Ports, Clean Oceans (1995) Controlling Garbage and Plastic Wastes at Sea. National Academy Press, Table 2-3, 38-39.

[29] Arokoyu, W.I. and Umeuduji, J.E. (2004) Perspective of the Human Environment. Amaethyst and Colleagues Publishers, Port Harcourt.

[30] International Maritime Organization (IMO) (2017) International Convention for the Prevention of Pollution from Ships (MARPOL), Adoption: 1973 (Convention), 1978 (1978 Protocol), 1997 (Protocol-Annex VI); Entry into force: 2 October 1983 (Annexes I and II).

http://www.imo.org/en/about/conventions/listofconventions/pages/international-co nvention-for-the-prevention-of-pollution-from-ships-(marpol).aspx 
[31] Ndigbo, O. (2017) Nigeria: Why Lagos Ports Are Congested. https://elombah.com

[32] AIS Marine Traffic (2017) Ports of ONNE (NG ONN) Marine Traffic Details. http://www.marinetraffic.com/en/ais/details/ports/803/Nigeria_port:ONNE

[33] Chi-Square Test of Independence. http://stattrek.com/chi-square-test/independence.aspx?Tutorial=AP

[34] Federal Environmental Protection Agency (FEPA) (1991) National Policy on the Environment. Federal Ministry of Environment, Abuja.

[35] Toepfer, K. (2016) Global International Waters Assessment (Giwa) Challenges to International Waters, Regional Assessments in a Global Perspective: GIWA Final Report. [Published by the United Nations Environment Programme in collaboration with GEF, the University of Kalmar and the Municipality of Kalmar, Sweden, and the Governments of Sweden, Finland, and Norway.] https://www.preventionweb.net/files/2365_giwafinalreport.pdf

[36] Schrooten, L., De Vlieger, I., Int Panis, L., Styns, R., Torfs, K. and Torfs, R. (2008) Inventory and Forecasting of Maritime Emissions in the Belgian Sea Territory, an Activity Based Emission Model. Atmospheric Environment, 42, 667-676. https://doi.org/10.1016/j.atmosenv.2007.09.071

[37] Abdellah, F.G. and Levine, E. (1979) Better Patient Care through Nursing Research. Macmillan Publishing Co. Inc., New York. 